\title{
HUBUNGAN ANTARA KEMANDIRIAN BELAJAR DENGAN HASIL BELAJAR IPA SISWA KELAS V SDN SEKECAMATAN KLIRONG TAHUN AJARAN 2020/2021
}

\author{
Rizki Kurnianto ${ }^{1}$, Tri Saptuti Susiani ${ }^{2}$, Muhamad Chamdani ${ }^{3}$ \\ Universitas Sebelas Maret \\ rizqikurnianto48@student.uns.ac.id
}

\section{Article History}

accepted 1/11/2021

\begin{abstract}
Students' natural science learning outcomes are varied. One of the internal factors that influence students' natural science learning outcomes is independence in learning. The study aimed to prove the positive correlation between independence in learning and natural science learning outcomes to fifth grade students of public elementary schools in Klirong Sub-district in academic year of 2020/2021 and to count the contribution of independence in learning on natural science learning outcomes to fifth grade students of public elementary schools in Klirong Sub-district in academic year of 2020/2021. The research was correlational quantitative method. Sampling method was cluster random sampling technique. Data analysis used the simple correlation test and determination coefficient. The result showed that there was positive and significant correlation between independence in learning and natural science learning outcomes to fifth grade students of public elementary schools in Klirong Sub-district in academic year of 2020/2021. Correlation coefficient was 0.426 and it indicated moderate correlation. It meant that the higher independence in learning, the higher natural science learning outcomes, and vice versa. Learning independence contributed $18.1 \%$ on science learning outcomes.
\end{abstract}

Keywords: independence in learning, natural science learning outcomes

\begin{abstract}
Abstrak
Hasil belajar IPA setiap siswa memiliki perbedaan. Salah satu faktor internal yang memengaruhi hasil belajar IPA siswa adalah kemandirian belajar. Penelitian ini bertujuan untuk membuktikan adanya hubungan positif antara kemandirian belajar dengan hasil belajar IPA siswa kelas $\mathrm{V}$ SDN se-Kecamatan Klirong tahun ajaran 2020/2021 dan menghitung besarnya sumbangan kemandirian belajar terhadap hasil belajar IPA siswa kelas V SDN se-Kecamatan Klirong tahun ajaran 2020/2021. Penelitian ini merupakan penelitian kuantitatif dengan metode korelasi. Pengambilan sampel dilakukan dengan menggunakan teknik cluster random sampling. Analisis data menggunakan uji korelasi sederhana dan rumus koefisien determinasi. Hasil penelitian menunjukkan bahwa terdapat hubungan positif dan signifikan antara kemandirian belajar dengan hasil belajar IPA siswa kelas V SDN se-Kecamatan Klirong tahun ajaran 2020/2021. Koefisien korelasi sebesar 0,426 dan berarti berada pada tingkat hubungan sedang. Hal tersebut berarti semakin tinggi kemandirian belajar, maka akan semakin tinggi pula hasil belajar IPA siswa, dan begitu pun sebaliknya. Kemandirian belajar memberikan sumbangan sebesar $18,1 \%$ terhadap hasil belajar IPA.
\end{abstract}

Kata kunci: kemandirian belajar, hasil belajar IPA 


\section{PENDAHULUAN}

Di abad ke-21 ini, pendidikan merupakan salah satu kebutuhan yang mendasar bagi manusia. Pendidikan merupakan hal yang penting sebagai bekal di masa depan karena dengan adanya pendidikan setiap individu diharapkan bisa mengembangkan kemampuannya sehingga bisa berguna bagi orang lain. Manusia berusaha untuk memperoleh pendidikan dengan tujuan agar potensi yang ada dalam dirinya berkembang melalui proses pembelajaran dan pengalaman. Pendidikan erat kaitannya dengan proses belajar. Belajar adalah usaha yang dilakukan seseorang dalam mendapatkan suatu perubahan tingkah laku baru secara keseluruhan, sebagai hasil dari pengalamannya sendiri dalam interaksi dengan lingkungannya (Slameto, 2010).

Salah satu mata pelajaran yang dipelajari di sekolah dasar adalah IImu Pengetahuan Alam (IPA). IPA merupakan ilmu yang mempelajari peristiwa-peristiwa yang terjadi di alam dengan melakukan observasi, eksperimentasi, penyimpulan, penyusunan teori agar siswa mempunyai pengetahuan, gagasan, dan konsep yang terorganisasi tentang alam sekitar, yang diperoleh dari pengalaman melalui serangkaian proses ilmiah antara lain penyelidikan, penyusunan, dan penyajian gagasan-gagasan (Oktari, Henny, \& Sri, 2018). Penguasaan IPA siswa dapat diukur melalui hasil belajar yang dicapai siswa. Menurut Susanto (2016) hasil belajar adalah perubahan-perubahan yang terjadi pada diri siswa yang menyangkut aspek kognitif, afektif, dan psikomotor sebagai hasil dari kegiatan belajar. Mahajan dan Singh (2017) menyatakan, "learning outcomes are statements of what a learner is expected to know, understand and/or be able to demonstrate after completion of a process of learning", yang artinya hasil belajar adalah pernyataan dari apa yang diharapkan oleh pelajar untuk diketahui, dipahami dan/atau dapat didemonstrasikan setelah menyelesaikan suatu proses pembelajaran. Berdasarkan pendapat tersebut dapat sisimpulkan bahwa hasil belajar IPA adalah kemampuan yang diperoleh siswa setelah mengikuti proses pembelajaran IPA yang terdiri dari aspek kognitif, afektif, dan psikomotor.

Hasil belajar yang diperoleh siswa dapat digunakan untuk mengukur tingkat keberhasilan belajar siswa. Tinggi rendahnya hasil belajar siswa dipengaruhi oleh beberapa faktor. Faktor-faktor tersebut meliputi faktor dari dalam diri siswa itu sendiri dan faktor yang berasal dari luar diri siswa. Faktor dari dalam diri siswa meliputi: kecerdasan, kemampuan berpikir kritis, motivasi, kesehatan, dan cara belajar serta kemandirian belajar. Sedangkan faktor yang berasal dari luar diri siswa meliputi: lingkungan keluarga, lingkungan sekolah, dan lingkungan masyarakat (Egok, 2016).

Kemandirian belajar merupakan salah satu faktor internal yang memengaruhi hasil belajar siswa. Tirtahardja dan Sulo (2018) menjelaskan kemandirian belajar dapat diartikan sebagai aktivitas belajar yang berlangsung lebih didorong oleh kemauan sendiri, pilihan sendiri, dan tanggung jawab sendiri dari diri pembelajar. Egok (2016) juga berpendapat bahwa kemandirian belajar adalah suatu usaha yang dilakukan untuk melakukan aktivitas belajar dengan cara mandiri atas dasar motivasinya sendiri untuk menguasai suatu materi tertentu sehingga bisa digunakan untuk memecahkan masalah yang sedang dihadapi. Berdasarkan pendapat tersebut dapat disimpulkan bahwa kemandirian belajar yaitu suatu aktivitas belajar atas kemauan dan kesadaran sendiri serta didorong oleh rasa tanggung jawab dalam usahanya mencapai tujuan belajar yaitu menguasai materi atau pengetahuan dengan baik serta mampu mengaplikasikan pengetahuannya dalam menyelesaikan masalah dalam kehidupan sehari-hari.'

Kemandirian belajar merupakan hal yang penting bagi siswa dan harus menjadi perhatian. Seperti dijelaskan oleh Ningsih dan Nurrahmah (2016) melalui kemandirian, siswa mampu mengatur dan mempunyai kemampuan untuk mengarahkan dirinya dan perasaannya tanpa terdapat pengaruh dari orang lain. Siswa yang mempunyai kemandirian belajar yang tinggi cenderung tidak bergantung kepada orang lain dan lebih berinisiatif untuk menyelesaikan persoalan yang dihadapinya sendiri tanpa 
mengharapkan bantuan dari orang lain. Dengan kemandirian belajar yang dimilikinya, siswa cenderung mempunyai inisiatif belajar yang lebih tinggi. Dengan demikian, kemandirian belajar memiliki peran penting dalam meningkatkan hasil belajar siswa. Setiap siswa memiliki kemandirian belajar yang berbeda-beda.

Pada kenyataannya, fakta yang terjadi di lapangan adalah siswa masih kurang mandiri dalam belajar ditandai dengan kurang inisiatifnya siswa dalam mengerjakan tugas yang diberikan guru dan siswa masih cenderung bergantung pada guru. Berdasarkan hasil wawancara dengan guru kelas $V$ di SDN 3 Kedungwinangun pada tanggal 2 Desember 2020 didapatkan informasi terkait kemandirian belajar siswa diantaranya: (1) masih terdapat beberapa siswa yang tidak mengerjakan PR/tugas yang diberikan oleh guru; (2) ada beberapa siswa yang mengumpulkan tugas tetapi bukan hasil pekerjaannya sendiri, yang dibuktikan dengan bentuk tulisan jelas bukan tulisan siswa; (3) siswa masih kurang inisiatif untuk mempelajari materi sendiri. Berdasarkan hasil Penilaian Tengah Semester (PTS) siswa kelas V di SDN 3 Kedungwinangun yang berjumlah 22 siswa pada mata pelajaran IPA diketahui sebesar $50 \%$ siswa belum tuntas dari KKM yang ditetapkan yaitu 70 . Dari pemaparan tersebut, dimungkinkan bahwa kemandirian belajar siswa memiliki hubungan dan memberikan kontribusi terhadap pencapaian hasil belajar IPA siswa. Pernyataan tersebut didukung dengan hasil penelitian dari Rahayu (2019) yang menyatakan bahwa terdapat hubungan positif antara kemandirian belajar terhadap hasil belajar IPA siswa kelas $\mathrm{V}$ SDN Gugus Wijaya Kusuma Kecamatan Ngaliyan Kota Semarang dengan tingkat hubungan sedang.

Ketercapaian hasil belajar IPA yang kurang maksimal disebabkan oleh beberapa faktor. Salah satu faktor internal internal yang memengaruhi hasil belajar IPA siswa adalah kemandirian belajar. Oleh karena itu, kemandirian belajar memiliki peranan yang penting dalam menunjang tercapainya tujuan pembelajaran dan siswa perlu ditumbuhkan sikap mandiri dalam belajar. Hal ini sesuai dengan pedapat dari Rafika, Israwati, dan Bachtiar (2017) yang menyatakan bahwa menumbuhkan kemandirian belajar siswa bertujuan untuk menguasai suatu kompetensi yang diharapkan sehingga tujuan pembelajaran tercapai baik dalam bentuk pengetahuan maupun keterampilan. Seseorang dikatakan mandiri apabila mampu bekerja sendiri, progresif, percaya diri, menghargai waktu, bertanggung jawab, dan mampu mengambil keputusan.

Berdasarkan uraian di atas, tujuan penelitian ini yaitu: (1) membuktikan adanya hubungan positif antara kemandirian belajar dengan hasil belajar IPA siswa kelas V SDN se-Kecamatan Klirong tahun ajaran 2020/2021; (2) menghitung besarnya sumbangan kemandirian belajar terhadap hasil belajar IPA siswa kelas V SDN seKecamatan Klirong tahun ajaran 2020/2021.

\section{METODE}

Penelitian ini merupakan penelitian kuantitatif dengan metode korelasi sederhana. Sukardi (2012) menyatakan penelitian korelasi adalah penelitian untuk menentukan hubungan dan tingkat hubungan antara dua variabel atau lebih dengan melibatkan tindakan pengumpulan data. Populasi penelitian ini adalah seluruh siswa kelas V di 32 SDN se-Kecamatan Klirong tahun ajaran 2020/2021 yang berjumlah 847 siswa dengan sampel sebanyak 303 siswa di 11 SDN di Kecamatan Klirong. Teknik sampling yang digunakan yaitu probability sampling jenis cluster random sampling.

Teknik pengumpulan data pada penelitian ini yaitu angket dan tes. Angket yang digunakan yaitu angket jenis skala likert berbentuk checklist. Angket digunakan untuk pengumpulan data pada variabel kemandirian belajar, sedangkan tes digunakan untuk mengumpulkan data pada variabel hasil belajar IPA. Instrumen terlebih dahulu diuji validitas dan reliabilitasnya sebelum akhirnya digunakan dalam penelitian.

Peneliti menggunakan aplikasi SPSS versi 21 dalam menguji hipotesis. Uji prasyarat analis data penelitian yaitu uji normalitas dan uji linieritas data. Uji normalitas 
menggunakan metode Kolmogorov Smirnov. Sedangkan uji linieritas dilakukan sebagai salah satu syarat untuk melakukan analisis korelasi data. Selanjutnya, analisis korelasi yang digunakan yaitu analisis korelasi Pearson Product Moment. Setelah melakukan analisis korelasi selanjutnya menghitung koefisien determinasi (KP). Koefisien determinasi pada penelitian ini menggunakan rumus menurut Riduwan dan Sunarto (2013) yaitu $\mathrm{KP}=\mathrm{r}^{2} \times 100 \%$.

\section{HASIL DAN PEMBAHASAN}

Penelitian ini dilakukan dengan memberikan angket kemandirian belajar dan tes hasil belajar IPA kepada kelas V di 11 SDN di Kecamatan Klirong yang menjadi sampel penelitian. Pada penelitian ini didapatkan jumlah sampel sebanyak 284 siswa dari total sampel 303 siswa.

Uji prasyarat analisis data telah terpenuhi yaitu data berasal dari populasi berdistribusi normal dan terdapat hubungan linier antara variabel kemandirian belajar dengan variabel hasil belajar IPA. Data hasil penelitian berasal dari populasi yang berdistribusi normal yang ditunjukkan dengan nilai signifikansi data variabel kemandirian belajar sebesar 0,200 dan nilai signifikansi data variabel hasil belajar IPA sebesar 0,092. Kedua nilai signifikansi data menunjukkan nilai $>0,05$ sehingga data tersebut berasal dari populasi berdistribusi normal.

Tabel 1. Hasil Analisis Uji Normalitas Variabel Kemandirian Belajar

Tests of Normality

\begin{tabular}{cccc} 
& \multicolumn{3}{c}{ Kolmogorov-Smirnova } \\
\cline { 2 - 4 } & Statistic & Df & Sig. \\
\hline Kemandirian Belajar & .042 & 284 & $.200^{*}$ \\
\hline
\end{tabular}

Tabel 2. Hasil Analisis Uji Normalitas Variabel Hasil Belajar IPA

Tests of Normality

\begin{tabular}{crcc}
\hline & \multicolumn{3}{c}{ Kolmogorov-Smirnov } \\
\cline { 2 - 4 } & Statistic & Df & Sig. \\
\hline Hasil Belajar IPA & .049 & 284 & .092 \\
\hline
\end{tabular}

Data dikatakan memiliki hubungan linier antara variabel $\mathrm{X}$ dan $\mathrm{Y}$ jika Sig. Deviation from Linearity $>0,05$. Nilai Sig. Deviation from Linearity dari analisis uji linieritas antara data variabel kemandirian belajar dengan data variabel hasil belajar IPA yaitu sebesar 0,194 . Artinya nilai $p$ value $>0,05$ sehingga dapat disimpulkan terdapat hubungan linier antara kemandirian belajar dengan hasil belajar IPA.

Tabel 3. Hasil Uji Linieritas Data Hasil Belajar IPA dan Kemandirian Belajar

\begin{tabular}{lllrc}
\multicolumn{5}{c}{ ANOVA Table } \\
\hline & & & F & Sig. \\
\hline Hasil Belajar & Between & (Combined) & 3.019 & .000 \\
\cline { 3 - 5 } IPA * & Groups & Linearity & 64.057 & .000 \\
\cline { 3 - 5 } Kemandirian & & Deviation from & 1.223 & .194 \\
Belajar & & Linearity & & \\
\hline
\end{tabular}

Korelasi antara kemandirian belajar dengan hasil belajar IPA diuji dengan menggunakan uji korelasi Pearson Product Moment. Uji korelasi menggunakan bantuan aplikasi SPSS versi 21 . Hipotesis yang digunakan adalah $\mathrm{Ho}=$ tidak ada 
hubungan positif antara kemandirian belajar dengan hasil belajar IPA dan $\mathrm{Ha}=$ ada hubungan positif antara kemandirian belajar dengan hasil belajar IPA.

Tabel 4. Hasil Analisis Korelasi Kemandirian Belajar dengan Hasil Belajar IPA

\begin{tabular}{llrr}
\hline \multicolumn{4}{c}{ Correlations } \\
& \multicolumn{2}{c}{$\begin{array}{c}\text { Kemandirian } \\
\text { Belajar }\end{array}$} & $\begin{array}{c}\text { Hasil Belajar } \\
\text { IPA }\end{array}$ \\
\hline \multirow{2}{*}{ Kemandirian Belajar } & Pearson Correlation & 1 & $.426^{* *}$ \\
\cline { 2 - 4 } & Sig. (1-tailed) & 284 & .000 \\
\cline { 2 - 4 } & $\mathrm{N}$ & $.426^{* *}$ & 284 \\
\hline Hasil Belajar IPA & Pearson Correlation & .000 & 1 \\
\cline { 2 - 4 } & Sig. (1-tailed) & 284 & 284 \\
\cline { 2 - 4 } & $\mathrm{N}$ & & \\
\hline${ }^{* *}$. Correlation is significant at the 0.01 level (1-tailed). & &
\end{tabular}

Setelah dilakukan analisis korelasi, tahap selanjutnya adalah mengitung koefisien determinasi untuk mengetahui besarnya sumbangan variabel kemandirian belajar terhadap hasil belajar IPA. Koefesien determinasi dihitung menggunakan rumus menurut Riduwan dan Sunarto (2013) dengan rumus sebagai berikut:

Nilai $r$ telah diketahui yaitu $r=0,426$

$$
K P=r^{2} \times 100 \%
$$

$$
\begin{aligned}
\mathrm{KP} & =(0,426)^{2} \times 100 \% \\
& =0,181 \times 100 \% \\
& =18,1 \%
\end{aligned}
$$

Berdasarkan analisis data menggunakan uji korelasi Pearson Product Moment, diketahui nilai Sig. (1-tailed) yaitu 0,000. Hal ini berarti nilai signifikansi $<\alpha(0,000<$ $0,05)$, artinya Ho ditolak atau berarti terdapat hubungan positif antara kemandirian belajar dengan hasil belajar IPA siswa kelas $\mathrm{V}$ SDN se-Kecamatan Klirong tahun ajaran 2020/2021 dengan nilai $r_{\text {hitung }}$ sebesar $0,426>r_{\text {tabel }}(0,116)$. Hasil penelitian ini sesuai dengan hasil penelitian dari Rahayu (2019) yang menyatakan bahwa terdapat hubungan positif antara kemandirian belajar terhadap hasil belajar IPA siswa kelas $\mathrm{V}$ SDN Gugus Wijaya Kusuma Kecamatan Ngaliyan Kota Semarang dengan tingkat hubungan sedang dengan $r$ hitung sebesar 0,593. Hasil penelitian dari Yanti, Trisoni, dan Fajar (2018) juga memperkuat hasil penelitian ini yang menunjukkan bahwa terdapat hubungan yang positif dan signifikan antara kemandirian belajar dengan hasil belajar IPA siswa kelas VIII di SMPN 1 Pariangan, Sumatera Barat dengan $\mathrm{r}_{\text {hitung }}$ $(0,783)>r_{\text {tabel }}(0,289)$.

Berdasarkan hasil penelitian telah diketahui bahwa kemandirian belajar memiliki hubungan yang positif dengan hasil belajar IPA. Oleh karena itu, dapat dikatakan bahwa semakin tinggi kemandirian belajar siswa, maka akan semakin tinggi pula hasil belajar IPA siswa. Begitu pun sebaliknya, semakin rendah kemandirian belajar siswa, maka akan rendah pula hasil belajar IPA siswa. Hal ini sesuai dengan pendapat Tahar (Saefullah, Siahaan, \& Sari, 2013) dalam penelitiannya meyimpulkan bahwa semakin tinggi sikap kemandirian belajar pada seseorang, maka memungkinkan orang tersebut mencapai hasil belajar yang lebih tinggi. Pendapat yang selaras diungkapkan oleh Simanullang dan Manurung (2017) dalam penelitiannya menyimpulkan bahwa jika kemandirian belajar tinggi, maka hasil belajar juga tinggi dan sebaliknya jika kemandirian belajar rendah, maka hasil belajar juga rendah. 
Hasil analisis koefisien korelasi antara variabel kemandirian belajar dengan hasil belajar IPA yaitu 0,426 . Berdasarkan pedoman interpretasi nilai koefisien korelasi versi De Vaus (Alaydrus \& Hardjomuljadi, 2018) dapat diketahui bahwa koefisien korelasi pada penelitian ini yaitu 0,496 berada pada tingkat hubungan moderat/sedang. Hubungan dalam kategori sedang pada penelitian ini artinya jika terjadi perubahan nilai pada variabel kemandirian belajar, maka akan diikuti oleh sebagian nilai dari variabel hasil belajar IPA. Tingkat hubungan yang sedang pada penelitian ini sejalan dengan hasil penelitian dari Rahmawati (2016) yang menyatakan bahwa terdapat hubungan positif dan signifikan antara kemandirian belajar dengan hasil belajar siswa SD Negeri Purwoyoso 06 Semarang dan termasuk dalam tingkat hubungan sedang dengan koefisien korelasi sebesar 0,560.

Hasil perhitungan koefisien determinasi dalam persen variabel kemandirian belajar pada hasil belajar IPA didapatkan hasil sebesar 18,1\%, artinya kemandirian belajar dapat berperan dalam meningkatkan hasil belajar IPA sebesar 18,1\% dan sisanya sebesar $81,9 \%$ dipengaruhi oleh faktor lain. Faktor-faktor lain yang memberikan sumbangan terhadap hasil belajar IPA seperti minat siswa, motivasi, dan lingkungan. Hal tersebut sesuai dengan penelitian Rosyidah (2010) yang menyatakan bahwa kemandirian belajar bukan satu-satunya variabel atau faktor yang menjadi penyebab tinggi rendahnya hasil belajar siswa, tetapi terdapat faktor-faktor lain yang memengaruhi tinggi rendahnya hasil belajar siswa baik faktor internal maupun eksternal seperti motivasi, sarana dan prasarana, disiplin, lingkungan sekolah, lingkungan keluarga, lingkungan masyarakat, guru, dan lainnya.

Kemandirian belajar merupakan strategi yang harus dimiliki oleh siswa dalam melaksanakan kegiatan belajar, sehingga didapatkan hasil belajar yang sesuai dengan keinginan dan cita-cita mereka (Primatahta, 2016). Oleh karena itu, kamandirian belajar memiliki peranan penting sebagai salah satu faktor yang menunjang tercapainya hasil belajar yang lebih baik, sehingga siswa perlu ditumbuhkan sikap mandiri dalam belajar.

Berdasarkan uraian di atas, dapat disimpulkan bahwa hasil penelitian ini telah sesuai dengan teori yang ada dan didukung pula dengan penelitian yang relevan, maka hasil penelitian ini adalah ada hubungan positif dan signifikan antara kemandirian belajar dengan hasil belajar IPA siswa kelas V SDN se-Kecamatan Klirong tahun ajaran 2020/2021.

\section{SIMPULAN}

Berdasarkan hasil penelitian dan pembahasan mengenai kemandirian belajar dan hasil belajar IPA siswa kelas V SDN se-Kecamatan Klirong tahun ajaran 2020/2021 dapat ditarik kesimpulan sebagai berikut:

1. Terdapat hubungan positif dan signifikan antara kemandirian belajar dengan hasil belajar IPA siswa kelas V SDN se-Kecamatan Klirong tahun ajaran 2020/2021 dengan tingkat korelasi sedang yaitu sebesar 0,426. Semakin tinggi kemandirian belajar, maka akan semakin tinggi pula hasil belajar IPA siswa. Begitu pun sebaliknya, semakin rendah kemandirian belajar, maka akan semakin rendah hasil belajar IPA siswa.

2. Sumbangan variabel kemandirian belajar terhadap hasil belajar IPA sebesar $18,1 \%$, sedangkan sisanya $81,9 \%$ dipengaruhi oleh faktor lain seperti kecerdasan, kesehatan jasmani, minat, bakat, perhatian, motivasi, kesiapan, ketekunan, kebiasaan belajar, faktor lingkungan, dan faktor yang lainnya. 


\section{DAFTAR PUSTAKA}

Alaydrus, A. M. \& Hardjomuljadi, S. (2018). Analisis Faktor Keterlambatan Dimulainya Pelaksanaan Proyek Konstruksi Pada Model Kontrak Rancang Bangun. Jurnal Konstruksia, 10(1), 95-116.

Egok, A. S. (2016). Kemampuan Berpikir Kritis dan Kemandirian Belajar dengan Hasil Belajar Matematika. Jurnal Pendidikan Dasar, 7(2), 186-199.

Mahajan, M. \& Singh, M. K. S. (2F017). Importance and Benefits of Learning Outcomes. Journal of Humanities And Sosial Science, 22(3), 65-67.

Ningsih \& Nurrahmah. (2016). Pengaruh Kemandirian Belajar dan Perhatian Orang Tua Terhadap Prestasi Belajar Matematika. Jurnal IImiah Pendidikan MIPA, 6(1), 73-84.

Oktari, S., Henny, D. K., \& Sri, G. (2018). Peningkatan Hasil Belajar IPA Dengan Model Problem Based Learning Berbantuan Media Audiovisual Kelas IV SD. Jurnal Pendidikan Berkarakter, 1(1), 316-323.

Primatahta, L. S. (2016). Hubungan antara Academic Goal Orientation dengan Kemandirian Belajar pada Siswa SMAN 3 Temanggung. Skripsi Tidak Dipublikasikan: Universitas Negeri Semarang.

Rafika, Israwati, \& Bachtiar. (2017). Upaya Guru dalam Menumbuhkan Kemandirian Belajar Siswa di SD Negeri 22 Banda Aceh. Jurnal IImiah Pendidikan Guru Sekolah Dasar, 2(1), 115-123.

Rahayu D. A. (2019). Hubungan Pola Asuh Orang Tua dan Kemandirian Belajar Terhadap Hasil Belajar IPA Siswa Kelas V SDN Gugus Wijaya Kusuma Kota Semarang. Skripsi Tidak Dipublikasikan: Universitas Negeri Semarang.

Rahmawati, D. (2016). Hubungan Kemandirian Belajar dengan Hasil Belajar Siswa SD Negeri Purwoyoso 06 Semarang. Skripsi Tidak Dipublikasikan: Universitas Negeri Semarang.

Riduwan \& Sunarto. (2013). Pengantar Statistika untuk Penelitian: Pendidikan, Sosial, Ekonomi, Komunikasi, dan Bisnis. Bandung: Alfabeta.

Rosyidah. (2010). Hubungan Antara Kemandirian Belajar dengan Hasil Belajar Matematika pada Siswa MTsN Parung-Bogor. Skripsi Tidak Dipublikasikan. Universitas Islam Negeri Syarif Hidayatullah.

Saefullah, A., Siahaan, P., \& Sari, I. M. (2013). Hubungan antara Sikap Kemandirian Belajar dan Prestasi Belajar Siswa Kelas X Pada Pembelajaran Fisika Berbasis Portofolio. Jurnal Wahana Pendidikan Fisika, 1(1), 26-36.

Simanullang W. K. \& Manurung, T. (2017). Hubungan Kemandirian Siswa dengan Hasil Belajar Biologi Siswa di Kelas XI IPA SMA YPN Marisi Medan Tahun Pembelajaran 2016/2017. Jurnal Pelita Pendidikan, 5(1), 86-93.

Slameto. (2010). Belajar dan Faktor-Faktor Yang Mempengaruhinya Edisi Revisi Cetakan ke-5. Jakarta: Rineka Cipta.

Sukardi. (2012). Metodologi Penelitian Pendidikan Kompetensi dan Praktiknya. Jakarta: PT Bumi Aksara.

Susanto, A. (2016). Teori Belajar \& Pembelajaran di Sekolah Dasar. Jakarta: Prenadamedia Group.

Tirtahardja, U. \& Sulo, L. (2018). Pengantar Pendidikan. Jakarta: Rineka Cipta.

Yanti, I., Trisoni, R, \& Fajar N. (2018). Hubungan Minat dan Kemandirian Belajar dengan Hasil Belajar IPA Siswa Pada Kelas VIII di SMP N 1 Pariangan. Prosiding Seminar Nasional Pendidikan Matematika dan Sains, hlm. 1-11. Batusangkar : IAIN Batusangkar. 